$\begin{array}{r}\text { Phinisi Integration Review } \\ \text { Vol. 1, No.2, Agustus 2018 Hal 177-189 } \\ \text { Website: http://ojs.unm.ac.id/pir } \\ \hline\end{array}$

\title{
Pengaruh Tingkat Pendidikan, Pendapatan Orang Tua, Dan Lingkungan Belajar Terhadap Hasil Belajar IPS Siswa
}

\author{
Sabriati \\ Program Pascasarjana Universitas Negeri Makassar \\ Email: sabriati93@gmail.com
}

\begin{abstract}
Abstrak. Penelitian ini bertujuan untuk mengetahui: (1) Pengaruh tingkat pendidikan orang tua terhadap hasil belajar IPS siswa di SMP Nusantara Makassar. (2) Pengaruh tingkat pendapatan orang tua terhadap hasil belajar IPS siswa di SMP Nusantara Makassar. (3) Pengaruh lingkungan belajar terhadap hasil belajar IPS siswa di SMP Nusantara Makassar. (4) Pengaruh tingkat pendidikan, pendapatan orang tua dan lingkungan belajar secara simultan terhadap hasil belajar IPS siswa di SMP Nusantara Makassar. Penelitian ini merupakan penelitiankuantitatif yang sifatnya Ex-PostFacto dengan sampel berjumlah 45 siswa. Pengumpulan data dilakukan dengan menggunakan angket dan dokumentasi. Teknik analisis data yang digunakan meliputi uji asumsi klasik (uji normalitas, uji linearitas, dan uji multikolinearitas), uji regresi sederhana dan uji regresi berganda. Hasil penelitian menunjukkan bahwa: (1) Terdapat pengaruh positif tingkat pendidikan orang tua terhadap hasil belajar IPS siswa di SMP Nusantara Makassar. (2) Tidak terdapat pengaruh tingkat pendapatan orang tua terhadap hasil belajar IPS siswa di SMP Nunsatara Makassar. (3) Terdapat pengaruh positif lingkungan belajar terhadap hasil belajar IPS siswa di SMP Nusantara Makassar. (4) Terdapat pengaruh positif tingkat pendidikan, tingkat pendapatan orang tua serta lingkungan belajar secara simultan terhadap hasil belajar IPS siswa di SMP Nusantara Makassar.
\end{abstract}

Kata Kunci: Pendidikan Orang Tua, Orang Tua, Lingkungan Belajar, Belajar IPS.

Abstract. The study aims at examining: (1) The influence of parents'education level on students' learning results inSocial Sciences atSMP Nusantara Makassar. (2) The influence of parents'income level on students' learning results in Social Sciences atSMP Nusantara Makassar. (3) The influence of learning environment on students' learning results in Social Sciences at SMP Nusantara Makassar. (4) The influence of education level, parents' income, and learning environment simultaneously on students' learning results in Social Sciencesat SMP Nusantara Makassar. The study is quantitative research with ExPost Facto with the total samples of 45 students. Data were collectedby employing questionnaire and documentation. Data were analyzed by employing statistics descriptive analysis and statistics inferential analysis. The results of the study reveal that: (1) There is positive influence of parents' education level on students' learning results in Social Sciences at SMP Nusantara Makassar. (2) There is no influence of parents' income level on students' learning results in Social Sciences at SMP Nusantara Makassar (3) There is positive influence of learning environment on students' learning results in Social Sciences at SMP Nusantara Makassar. (4) There ispositive influence of education level, of parents' income level and learning environment simultaneously on students' learning results in Social Sciences at SMP Nusantara Makassar.

Keywords: Parents' level, parents' income level, environment, students' Social Sciences. 


\section{PENDAHULUAN}

Sumber daya manusia yang paling banyak disoroti dan menjadi tempat tumpuan harapan oleh masyarakat dalam kelangsungan pembangunan selanjutnya adalah para generasi muda. Generasi muda agar dapat menjadi aset pembangunan bangsa yang handal setidaknya harus memiliki berbagai kemampuan dan kecapakan pribadi. Hal tersebut dipertegas dalam Undang-Undang No. 20 Tahun 2003 tentang Sistem Pendidikan Nasional Pasal 1 Ayat 1 menyatakan bahwa Pendidikan adalah usaha sadar dan terencana untuk mewujudkan suasana belajar dan proses pembelajaran agar peserta didik aktif mengembangkan potensi dirinya untuk memiliki kekuatan spiritual keagamaan, pengendalian diri, kepribadian, kecerdasan, akhlak mulia, serta keterampilan yang diperlukan dirinya, masyarakat dan negara.

Berhasilnya tidaknya suatu proses belajar mengajar dapat diketahui dari hasil belajar yang diperoleh siswa. Hasil belajar IPS menjadi salah satu tolok ukur kualitas pendidikan di sekolah. Hasil Belajar IPS adalah tingkat pengetahuan, keterampilan, dan penguasaan mata pelajaran IPS yang dicapai dalam proses pembelajaran IPS selama jangkawaktu tertentu dan dinyatakan dalam suatu nilai yang diperoleh dari tesevaluasi. Dengan memahami mata pelajaran IPS diharapkan siswa tersebut mampu mengatasi malasah-masalah sosial yang terjadi di lingkungan sekitar yang telah diterima selama mengikuti proses belajar di sekolah. Hasil belajar pada umumnya dikaitkan dengan tinggi rendahnya nilai yangdicapai oleh siswa,dayaserap siswa yang berupa nilai rapor.

Hasil belajar siswa bukanhanya karena faktor kecerdasan siswa saja, tetapi ada factor lain yang dapat mempengaruhi hasil belajar siswa tersebut,salah satu faktor yang mempengaruhi hasil belajar siswa yaitu latar belakang pendidikan orang tua. Tingkat pendidikan atau kebiasaan dalam keluarga mempengaruhi sikap anak dalam belajar. Orangtua yang memiliki tingkat pendidikan tinggi biasanya memiliki cita-cita tinggi pula terhadap pendidikan anak-anaknya. Mereka menginginkan agar pendidikana nak-anaknya lebih tinggi atau setidaknya sama dengan pendidikan orang tua mereka, cita-cita dan dorongan ini akan mempengaruhi sikap dan keberhasilan anak-anaknya di sekolah.

Selain latar belakang pendidikan orang tua, faktor lain yang mempengaruhi hasil belajar siswa yaitu keadaan ekonomi keluarga. Keadaan ekonomi keluarga erat kaitannya dengan belajar anak. Anak yang sedang belajar selain harus terpenuhi kebutuhan pokoknya, misal makan, pakaian, perlindungan kesehatan dan lain-lain, juga membutuhkan fasilitas belajar seperti ruang belajar, meja, kursi, penerangan, alat tulismenulis, buku-buku dan lain-lain. Jika anak hidup dalam keluarga miskin, kebutuhan pokok anak kurang terpenuhi, akibatnya kesehatan anak terganggu, sehingga belajar anak juga terganggu. Akibat yang lain anak selalu dirundung kesedihan sehingga anak merasa minder dengan teman lain, hal ini pasti akan mengganggu belajar anak. Bahkan mungkin anak harus bekerja mencari nafkah sebagai pembantu orang tuanya walaupun sebenarnya anak belum saatnya untuk bekerja, hal yang begitu juga akan membantu belajar anak. Walaupun tidak dapat dipungkiri tentang adanya kemungkinan anak yang serba kekurangan dan selalu menderita akibat ekonomi keluarga yang lemah, justru keadaan yang begitu menjadi cambuk baginya untuk belajar lebih giat dan akhirnya sukses besar. Sebaliknya keluarga yang kaya raya, orang tua yang sering mempunyai kecenderungan untuk memanjakan anak. Anak hanya bersenang-senang dan berfoya-foya, akibatnya anak kurang dapat memusatkan perhatian kepada belajar. Hal tersebut juga dapat mengganggu belajar anak.

Latar belakang pendidikan dan pendapatan orang tua yang tinggi akan kurang maksimal jika tidak didukung oleh lingkungan belajar yang kondusif. Keadaan lingkungan belajar seperti bangunan rumah, suasana sekitar, keadaan lalu lintas, iklim serta sarana dan prasana memadai sangat berpengaruh terhadap hasil belajar yang diperoleh anak. Misalnya bila bangunan rumah penduduk sangat rapat, akan mengganggu belajar. Keadaan lalu lintas yang membisingkan, suara hiruk-pikuk orang di sekitar, suara pabrik, polusi udara, iklim yang terlalu panas, semuanya akan mempengaruhi belajar anak. Sebaliknya, tempat yang sepi dan iklim yang sejuk akan menunjang proses belajar anak.

SMP Nusantara merupakan salah satu sekolah yang berada di bawah naungan Yayasan Pendidikan Kanak-Kanak Nusantara. SMP Nusantara diresmikan oleh Ny. E. Jusuf pada hari Sabtu, tanggal 21 Mei 1977. Dengan jumlah siswa sebanyak 83 orang. Kualifikasi pendidikan orang tua siswa sebagian besar 
memiliki tingkat pendidikan yang tinggi sehingga berpeluang untuk mendapatkan pendapatan yang tinggi. Dengan adanya penghasilan yang tinggi tersebut maka orang tua bisa menyediakan lingkungan belajar yang memadai untuk anaknya, khususya dalam memilih sekolah yang dianggap berkualitas. Salah satu pertimbangan dalam memilih sekolah, yaitu lokasi yang strategis, sarana dan prasarana yang tersedia. SMP Nusantara merupakan sekolah yang terletak di Jalan Ahmad Yani No. 19-A Makassar.

Berdasarkan observasi yang telah dilakukan, ada 23siswa atau kurang dari28\%siswayangbelumtuntasdalampencapaian hasil belajar IPSsesuaidenganKriteria KetuntasanMinimum(KKM)yang

diterapkanuntukmata

pelajaranIPSyaitumencapainilai75.Siswa

mengalami problemkesulitanmemahami pelajaranIPS dikarenakan rendahnyadaya serapmata pelajaranIPS.Halinidapatmengganggu dan menghambatsiswadalam usahapencapaianhasil sesuaiyangdiharapkan.

Adapun penelitian pendukung yang relevan yaitu penelitian yang dilakukan oleh Cholifah, dkk. (2016), menunjukkan bahwa adapengaruhpositif dansignifikanantaralatar belakangtingkatpendidikanorang tuaterhadap hasilbelajarsiswakelas

SDNKecamatanSananwetanKota

BlitardengannilaiR67,6\%. Adapun, penelitian Sapruddin, dkk (2017), menunjukkan prestasi belajar IPS yang rendah dipengaruhi oleh faktor kondisi sosial ekonomi yang rendah dan motivasi belajar yang rendah. Selain itu, penelitian Atya Rizkiana (2014), menunjukkan bahwa terdapat pengaruh sebesar $77,9 \%$ status sosial ekonomi orang tua, motivasi belajar dan disiplin belajar terhadap prestasi belajar siswa.

Berdasarkan beberapa penelitian pendukung yang relevan,maka penelititertarikuntukmelakukan

penelitiantentangpengaruh tingkat pendidikan, pendapatan orang tua dan lingkungan belajar terhadap hasil belajar IPS siswa di SMP Nusantara Makassar.

Berdasarkan latar belakang maka dirumuskan masalah, yaitu: (1) Bagaimanakah pengaruh tingkat pendidikan orang tua terhadap hasil belajar IPS Siswa di SMP Nusantara Makassar? (2) Bagaimanakah pengaruh tingkat pendapatan orang tua terhadap hasil belajar IPS Siswa di SMP Nusantara Makassar?
Bagaimanakah pengaruh lingkungan belajar terhadap hasil belajar IPS siswa di SMP Nusantara Makassar? (4) Bagaimanakah pengaruh tingkat pendidikan, pendapatan orang tua dan lingkungan belajar secara simultan terhadap hasil belajar IPS Siswa di SMP Nusantara Makassar?

Pelaksanaan penelitian ini bertujuan untuk: (1) Untuk mengetahui pengaruh tingkat pendidikan orang tua terhadap hasil belajar IPS Siswa di SMP Nusantara Makassar. (2) Untuk mengetahui pengaruh tingkat pendapatan orang tua terhadap hasil belajar IPS Siswa di SMP Nusantara Makassar. (3) Untuk mengetahui pengaruh lingkungan belajar terhadap hasil belajar IPS siswa di SMP Nusantara Makassar. (4) Untuk mengetahui pengaruh tingkat pendidikan, pendapatan orang tua dan lingkungan belajar secara simultan terhadap hasil belajar IPS Siswa di SMP Nusantara Makassar.

Hasil penelitian ini diharapkan dapat memberikan manfaat baik secarateoritis maupun secarapraktis.

\section{Deskripsi Teoritis}

\section{Tingkat Pendidikan Orang Tua}

Pendidikan berkenaan dengan perkembangan dan perubahan kelakuan anak didik. Pendidikan bertalian dengan transmisi pengetahuan, sikap, kepercayaan, keterampilan, dan aspek-aspek kelakuan lainnya kepada generasi muda. Pendidikan adalah proses mengajar dan belajar pola-pola kelakuan manusia menurut apa yang diharapkan oleh masyarakat (Nasution, 2014: 10).

Tugas dan tanggung jawab orang tua dalam keluarga terhadap pendidikan anakanaknya lebih bersifat pembentukan watak dan budi pekerti, latihan keterampilan dan pendidikan kesosialan, seperti tolong-menolong, bersama-sama menjaga kebersihan rumah, menjaga kesehatan dan ketentraman rumahh tangga dan sejenisnya. Agar orang tua dapat melaksanakan tugas dan tanggung jawab tersebut maka orang tua perlu dibekali dengan pengetahuan dan keterampilan pendidikan (Ihsan, 2013: 58).

Menurut UU RI No. 20 Tahun 2003 Tentang Sistem Pendidikan Nasional Pasal 1 Ayat 11 tentang pendidikan formal adalah jalur pendidikan yang terstruktur dan berjenjang yang terdiri atas pendidikan dasar, pendidikan menengah, dan pendidikan tinggi. Untuk lebih jelas tentang ruang lingkup pendidikan dasar, 
pendidikan menengah, dan pendidikan tinggi dapat dilihat pada Pasal 17, 18 serta 19 berikut:

a. Pasal 17 Ayat 2 tentang Pendidikan Dasar berbunyi pendidikan dasar berbentuk Sekolah Dasar (SD) dan Madrasah Ibtidaiyah (MI) atau bentuk lain yang sederajat serta Sekolah Menengah Pertama (SMP) dan Madrasah Tsanawiyah (MTs), atau bentuk lain yang sederajat.

b. Pasal 18 Ayat 3 tentang Pendidikan Menengah berbunyi pendidikan menengah berbentuk Sekolah Menengah Atas (SMA), Madrasah Aliyah (MA), Sekolah Menengah Kejuruan (SMK), dan Madrasah Aliyah Kejuruan (MAK), dan bentuk lain yang sederajat.

c. Serta Pasal 19 Ayat 1 tentang pendidikan tinggi berbunyi pendidikan pendidikan tinggi merupakan jenjang pendidikan setelah pendidikan menengah yang mencakup program pendidikan diploma, sarjana, magister, spesialis dan doktor yang diselenggarakan oleh perguruan tinggi.

Dalam penelitian ini yang dimaksud pendidikan orang tua adalah pendidikan terahir yang di tempuh oleh ayah/ibu siswa yang meliputi pendidikan dasar, pendidikan menengah, S1, S2, serta S3). Karena setiap tingkatan jenjang pendidikan akan berpengaruh terhadap cara berpikir seseorang.

\section{Pendapatan Orang Tua}

Menurut Sumardi dalam Hamran (2016: 16) pendapatan adalah jumlah penghasilan riil seluruh anggota keluarga yang disumbangkan untuk memenuhi kebutuhan bersama maupun perseorangan dalam keluarga.

Perkembangan ilmu pengetahuan dan teknologi dewasa ini serta bentuk kehidupan yang semakin mengglobal maka orang tua, guru dan masyarakat dituntut untuk mencari alternatif terhadap pembinaan dan pengembangan wawasan anak.Tri pusat pendidikan yaitu lingkungan, keluarga, masyarakat mempunyai peranan penting sebagai wadah pembinaan anak, harus kerjasama dan saling menunjang.

Orang tua yang mengertiakan kebutuhan anak selalu menyiapkan sarana pendidikan, dengan demikian dapat dipahami bahwa peranan orang tua salah satunya adalah memberikan fasilitas belajar kepada anaknya, dan sangat berpengaruh terhadap pencapaian belajar seorang anak. Dengan demikian, orang tua perlu menyediakan fasilitas belajar yang memadai, sehingga diperlukan tingkat ekonomi orang tua yang memadai pula.

Besar pendapatan yang diterima oleh setiap orangtua akan berbeda antara yang satu dengan yang lain, hal ini karena dipengaruhi oleh keadaan orangtua sendiri dalam melakukan berbagai macam kegiatan seharihari. Pendapatan yang diterima oleh seseorang akan dipengaruhi oleh tingkat pendidikan yang dimilikinya. Dengan pendidikan yang tinggi akan dapat memperoleh kesempatan yang lebih untuk mendapatkan pekerjaan yang lebih baik dan serta mendapatkan pendapatan yang lebih besar. Sedangkan bagi seorang yang berpendidikan rendah akan mendapat pekerjaan dengan pendapatan yang kecil.

Berdasarkan Keputusan Gubernur Sulsel Nomor 2233/XI/Tahun 2016 tentang penetapan Upah Minimum Provinsi Sulawesi Selatan tahun 2016. Pemerintah Provinsi Sulawesi Selatan menetapkan kenaikan Upah Mininum Provinsi (UMP) 2017, sebesar 10 persen atau menjadi Rp. 2.500.000,(http://sulselprov.go.id). Berlandasarkan pada UMP tersebut penggolongan pendapatan dapat digolongkan menjadi 5 golongan yaitu:

a. Golongan orang tua berpendapatan sangat rendah, yaitu orang tua yang berpedapatan dibawah Rp. 2.500.000,- perbulan.

b. Golongan orang tua berpendapatan rendah, yaitu orang tua yang berpendapatan rata-rata Rp. 2.500.000,perbulan.

c. Golongan orang tua berpendapat cukup tinggi, yaitu orang tua yang berpendapatan rata-rata antara Rp. 2.500.000,- sampai Rp. 3.500.000,- perbulan.

d. Golongan orang tua berpendapat tinggi, yaitu orangtua yang berpendapatan rata-rata antara Rp. 3.500.000,- sampai Rp. 4.500.000,-perbulan.

e. Golongan orangtua berpendapatan sangat tinggi yaitu orangtua dengan pendapatan rata-rata lebih dari Rp. 4.500.000,perbulan.

Berdasarkan pemaparan tersebut dapat dipahami bahwa yang dimaksud dengan pendapatan orangtua adalah penghasilan berupa uang yang diterima sebagai balas jasa dari kegiatan baik dari sektor formal dan informal selama satu bulan dalam satuan rupiah.

\section{Lingkungan Belajar}

Lingkungan adalah segala sesuatu yang ada di luar diri individu. Adapun lingkungan pengajaran merupakan segala apa yang bisa mendukung pengajaran itu sendiri yang dapat 
difungsikan sebagai "sumber pengajaran" atau "sumber belajar" (Rohani, 2010: 22).

Menurut Syah (2016: 135-136)

lingkungan belajar terbagi menjadi dua yaitu:

a. Lingkungan sosial

Lingkungan sosial sekolah seperti para guru, para tenaga kependidikan (kepala sekolah dan wakil-wakilnya dan teman-teman sekelas dapat memengaruhi semangat belajar seorang siswa. Para guru yang selalu menunjukkan sikap dan perilaku yang simpatik dan memperlihatkan suri teladan yang baik dan rajin khususnya dalam hal belajar, misalnya rajin membaca dan berdiskusi, dapat menjadi daya dorong yang positif bagi kegiatan belajar siswa.

b. Lingkungan nonsosial

Faktor-faktor yang termasuk lingkungan nonsosial ialah gedung sekolah dan letaknya, rumah tempat tinggal keluarga siswa dan letaknya, alat-alat belajar, keadaan cuaca dan waktu belajar yang digunakan siswa. Faktorfaktor ini dipandang turut menentukan tingkat keberhasilan belajar siswa.

Menurut Wahab (2015: 26) lingkungan belajar meliputi:

1. Lingkungan sosial

1. Lingkungan sosial masyarakat

Kondisi lingkungan masyarakat tempat tinggal siswa akan memengaruhi hasil belajar siswa. Lingkungan siswa yang kumuh, banyak pengangguran dan anak terlantar juga dapat memengaruhi aktivitas belajar siswa, paling tidak siswa kesulitan ketika memerlukan teman belajar, diskusi, atau meminjam alat-alat belajar yang kebetulan belum dimilikinya.

2. Lingkungan sosial keluarga

Lingkungan ini sangat memengaruhi kegiatan belajar. Ketegangan keluarga, sifatsifat orang tua, demografi keluarga (letak rumah), pengelolaan keluarga, semuanya dapat memberi dampak terhadap aktivitas belajar siswa. Hubungan antara anggota keluarga, orang tua, anak, kakak, atau adik yang harmonis akan membantu siswa melakukan aktivitas belajar dengan baik.

3. Lingkungan sosial sekolah

Seperti guru, administrasi, dan temanteman sekelas dapat memengaruhi proses belajar seorang siswa. Hubungan yang harmonis antara ketiganya dapat menjadi motivasi bagi siswa untuk belajar lebih baik di sekolah. Maka para pendidik, orang tua, dan guru perlu memperhatikan dan memahami bakat yang dimiliki oleh anaknya atau peserta didiknya, antara lain dengan mendukung, ikut mengembangkan, dan tidak memaksa anak untuk memilih jurusan yang tidak sesuai dengan bakatnya.

2. Lingkungan nonsosial

1. Lingkungan alamiah

Seperti kondisi udara segar, tidak panas dan tidak dingin, sinar yang tidak terlalu silau/kuat, atau tidak terlalu lemah/gelap, suasana yang sejuk dan tenang. Lingkungan alamiah tersebut merupakan faktor-faktor yang dapat memengaruhi aktivitas belajar siswa. Sebaliknya bila kondisi lingkungan alam tidak mendukung, proses belajar siswa akan terhambat.

2. Lingkungan instrumental

Yaitu perangkat belajar yang dapat digolongkan dua macam. Pertama, hardware (perangkat keras), seperti gedung sekolah, alatalat belajar, fasilitas belajar, lapangan olahraga, dan lain sebagainya. Kedua, software (perangkat lunak), seperti kurikulum sekolah, peraturanperaturan sekolah, buku panduan, silabus, dan lain sebagainya.

Berdasarkan berbagai pendapat tersebut dapat dipahami bahwa lingkungan belajar yang mempengaruhi hasil belajar siswa meliputi lingkungan sosial dan lingkungan non sosial.

\section{Hasil belajar IPS}

Pengertian belajar menurut Slameto(2013:2) yaitu "suatu prosesusahayang dilakukanseseorang untukmemperolehsuatu perubahantingkahlakuyang

barusecarakeseluruhan,sebagai hasil pengalamannyasendiri dalam interaksi dengan lingkungannya".

Senada dengan Slameto, Syah (2016: 90) juga mengemukakan bahwa " belajar adalah tahapan perubahan seluruh tingkah laku individu yang relatif menetap sebagai hasil pengalaman dan interaksi dengan lingkungan yang melibatkan proses kognitif".

Menurut Nawawi dalam Hamalik (2015: 67) hasil belajar yaitu tingkat keberhasilan siswa dalam mempelajari materi pelajaran di sekolah yang dinyatakan dalam bentuk skor, diperoleh dari hasil tes, mengenai materi pelajaran yang telah disajikan.

Ilmu pengetahuan sosial (IPS) merupakan integrasi dari berbagai cabang ilmuilmu sosial dan humaniora, yaitu: sosiologi, sejarah, geografi, ekonomi, politik, hukum dan budaya. Ilmu pengetahuan sosial dirumuskan atas dasar realitas dan fenomena sosial yang mewujudkan suatu pendekatan interdisipliner dari aspek dan cabang-cabang ilmu sosial. 
(Susanto, 2014: 6)

Berdasarkan berbagai pendapat dapat dipahami bahwa "hasil belajar ips adalah tingkat keberhasilan siswa dalam mempelajari integrasi dari berbagai disiplin ilmu sosial dan humaniora di sekolah yang dinyatakan dalam bentuk skor, diperoleh dari hasil tes, mengenai materi pelajaran ips yang telah disajikan.

Hasil belajar yang dicapai siswa dipengaruhi oleh dua faktor utama yakni faktor dari dalam diri siswa dan faktor yang dari luar diri siswa atau faktor lingkungan. Selain faktor kemampuan yang dimiliki siswa juga ada faktor lain seperti motivasi belajar, minat dan perhatian, sikap dan kebiasaan belajar, ketekunan, sosial ekonomi, faktor fisik dan psikis (Sudjana, 2014: 39).

Menurut Slameto, 2013: 54 faktorfaktor yang mempengaruhi belajar yaitu:

a. Faktor jasmaniah meliputi: faktor kesehatan dan cacat tubuh.

b. Faktor psikologis meliputi: intelegensi, perhatian, minat, bakat, motif, kematangan, serta kesiapan.

c. Faktor kelelahan.

d. Faktor keluarga meliputi: cara orang tua mendidik, relasi antaranggota keluarga, suasana rumah, keadaan ekonomi keluarga, pengertian orang tua, serta latar belakang kebudayaan/tingkat pendidikan orang tua.

e. Faktor sekolah meliputi: metode mengajar, kurikulum, relasi guru dengan siswa, relasi siswa dengan siswa, disiplin sekolah, alat pelajaran, waktu sekolah, standar pelajaran di atas ukuran, keadaan gedung, metode belajar, serta tugas rumah.

f. Faktor masyarakat meliputi: kegiatan siswa dalam masyarakat, mass media, teman bergaul, serta bentuk kehidupan masyarakat.

Adapun faktor yang mempengaruhi proses dan hasil belajar menurut Djamarah (2015: 177) yaitu:

a. Faktor lingkungan meliputi: lingkungan alami dan lingkungan sosial budaya,

b. Faktor instrumental meliputi: kurikulum, program, sarana dan fasilitas serta guru,

c. Faktor fisiologis meliputi: kondisi fisiologis dan kondisi pancaindra

d. Faktor psikologis meliputi: minat, kecerdasan, bakat, motivasi, serta kemampuan kognitif.

Selain itu Dalyono (2015: 55) mengemukakan faktor-faktor yang mempengaruhi belajar yaitu:

a. Faktor internal meliputi: kesehatan, intelegensi dan bakat, minat dan motivasi, serta cara belajar.

b. Faktor eksternal meliputi: keluarga, sekolah, masyarakat, serta lingkungan sekitar.

Berdasarkan berbagai pendapat ahli tersebut dalam penelitian ini yang menjadi fokus dalam faktor-faktor yang mempengaruhi hasil belajar siswa yaitu tingkat pendidikan dan pendapatan orang tua serta lingkungan belajar anak.

Adapun ranah hasil belajar menurut Syah (2012: 217-218) meliputi:

a. Ranah cipta (kognitif) mencakup pengamatan, ingatan, pemahaman, aplikasi/penerapan, analisis (pemeriksaan dan pemilahan secara teliti), serta sintesis (membuat paduan baru dan utuh).

b. Ranah rasa (afektif) mencakup penerimaan, sambutan, apresiasi (sikap menghargai), internalisasi (pendalaman), serta karakterisasi (penghayatan).

c. Ranah karsa (psikomotor) mencakup keterampilan bergerak dan bertindak srta kecakapan ekspresi verbal dan non-verbal.

Berdasarkan pendapat tersebut dapat dipahami bahwa untuk mengukur prestasi belajar siswa itu memerlukan tiga aspek yakni, kognitif (pengetahuan), afektif (sikap), serta psikomotorik (keterampilan). Ketiga aspek tersebut dapat dilihat dari nilai rapor yang diperoleh oleh siswa.

\section{METODE}

Jenis penelitian yang digunakan adalah penelitian kuantitatif yang sifatnya Ex-Post Facto. Menurut Sukardi (2012:15)"Penelitian Ex-Post Facto adalah penelitian dimana variabel-variabel bebas telah terjadi ketika penelitian mulai dengan pengamatan variable terikat dalam suatu penelitian". Adapun pendekatan data kuantitatif adalah semua informasi atau data yang diperoleh diwujudkan dengan angka. Hasil penelitian yang berwujud data kuantitatif akan dianalisis dengan teknik statistika.

Ditinjau dari tujuannya, penelitian ini merupakan penelitian kausal komparatif. Menurut Sukardi (2012: 171), penelitian kausal komparatif melibatkan kegiatan peneliti yang diawali dari mengidentifikasi pengaruh variable satu terhadap variable lainnya, kemudian berusaha mencari kemungkinan variable penyebabnya. Penelitian ini ditunjukkan untuk mengetahui pengaruh tingkat pendidikan, 
pendapatan orang tua dan lingkungan belajar terhadap hasil belajar IPS siswa di SMP Nusantara Makassar.

Dalam penelitian yang menjadi variabel bebas adalah tingkat pendidikan orang tua $\left(\mathrm{X}_{1}\right)$, tingkat pendapatan orang tua $\left(\mathrm{X}_{2}\right)$ serta lingkungan belajar $\left(\mathrm{X}_{3}\right)$, sedangkan variabel terikat hasil belajar siswa $(\mathrm{Y})$.

Penelitian ini dilakukan di SMP Nusantara Makassar yang beralamat di Jalan Ahmad Yani No. 19A Makassar. Adapun rentang waktu penelitian yaitu pada bulan Agustus tahun 2017 sampai dengan bulan Januari Tahun 2018.

Definisi operasional dari penelitian ini adalah sebagai berikut:

a. Tingkat pendidikan orang tua adalah pendidikan terakhir yang ditempuh oleh orang tua siswa yang meliputi: SD, SMP, SMA, Diploma, S1, S2 serta S3. Kemudian untuk mempermudah pengolahan data maka diberi pemisalan 1 untuk SD dan seterusnya sampai 7 untuk S3.

b. Tingkat pendapatan orang tua adalah upah atau balas jasa berupa uang yang diterima orang tua atas pekerjaan yang telah dilakukan dalam jangka satu bulan. Dengan rentang mulai dibawah Rp. 2.500.000,perbulan sampai diatas Rp. 4.500.000,perbulan. Kemudian untuk mempermudah pengolahan data maka diberi pemisalan 1 untuk pendapatan dibawah Rp. 2.500.000,dan seterusnya sampai 5 untuk pendapatan diatas Rp. 4.500.000,-.

c. Lingkungan belajar siswa yang dimaksudkan dalam penelitian ini adalah tempat maupun sarana dan prasarana di mana siswa melakukan kegiatan belajar. Angket lingkungan belajar terdiri dari 5 pilihan jawaban dengan skor 1-5.

d. Hasil belajar siswa yang dimaksudkan dalam penelitian ini adalah hasil yang dicapai oleh siswa setelah melalui proses belajar yang diperoleh dari nilai rapor. Hasil belajar terdiri dari 5 kategori mulai dari tidak baik sampai sangat baik.

Adapun populasi dalam penelitian ini adalah semua siswa SMP Nusantara Makassar yaitu sebanyak 83 siswa. Penarikan sampel dalam penelitian ini akan menggunakan stratified proportional random sampling.

Adapun besarnya ukuran sampel yang digunakan ditentukan dengan menggunakan rumus yang dikemukakan oleh Slovin dalam Munarfah (2009: 81). Berdasarkan perhitungan data diperoleh jumlah sampel sebanyak 45 siswa. Dari jumlah sampel 45 siswa, kemudian ditentukan jumlah masing-masing sampel yang berada disetiap kelas secara proportionate random sampling.

Untuk memperoleh data yang dibutuhkan dalam penelitian ini peneliti menggunakan beberapa teknik pengumpulan data berupa angket dan dokumentasi.Angket penulis gunakan untuk memperoleh data mengenai tingkat pendidikan, pendapatan orang tua dan lingkungan belajar. Sedangkan dokumentasi diperlukan terutama untuk mendapatkan data tentang hasil belajar IPS siswa, karena dalam metode ini dapat diperoleh data-data histories, seperti sejarah berdirinya SMP Nusantara Makassar, visi dan misi sekolah, daftar guru IPS, daftar siswa, dokumen seperti jurnal, agenda, dan keadaan hasil belajar siswa, pendidikan dan pendapatan yang dimiliki oleh orang tua siswa serta data lain yang mendukung penelitian ini. Dokumentasi juga dijadikan sebagai barang bukti bahwa kita benar telah melaksanakan penelitian yang dapat dilihat pada daftar lampiran dokumentasi penelitian.

\section{HASIL DAN PEMBAHASAN}

\section{1a.Deskripsi Tingkat Pendidikan Orang Tua di SMP Nusantara Makassar}

Berdasarkan olah data angket dapat diketahui bahwa tingkat pendidikan orang tua di SMP Nusantara Makassar terbanyak yaitu pada jenjang pendidikan tinggi dengan frekuensi 63 orang dan presentase $70 \%$, selanjutnya pada jenjang pendidikan menengah sebanyak 27 orang dengan persentase $30 \%$. Adapun berdasarkan hasil olah data SPPS for Windows 21 diperoleh nilai mean sebesar 80, 44 dengan standar deviasi sebesar 11, 273 serta nilai varians sebesar 127,071.

\section{1b. Deskripsi Tingkat Pendapatan Orang Tua di SMP Nusantara Makassar}

Berdasarkan hasil olah data angket dapat diketahui bahwa tingkat pendapatan orang tua di SMP Nusantara Makassar berada pada kategori cukup tinggi dengan frekuensi 35 orang dan presentase 38,89\%. Adapun berdasarkan hasil olah data SPPS for Windows 21 diperoleh nilai mean sebesar 77,33 dengan standar deviasi sebesar 9,145 serta nilai varians sebesar 83,636.

\section{1c. Deskripsi Lingkungan Belajar Siswa di SMP Nusantara Makassar}

Berdasarkan hasil olah data angket dapat diketahui bahwa lingkungan belajar di 
SMP Nusantara Makassar berada pada kategori baik dengan frekuensi 24 orang dan presentase 53,3\%. Adapun berdasarkan hasil olah data SPPS for Windows 21 diperoleh nilai mean sebesar 85,00 dengan standar deviasi sebesar 9,288 serta nilai varians sebesar 86, 273.

\section{1d. Deskripsi Hasil Belajar Siswa di SMP Nusantara Makassar}

Berdasarkan hasil dokumentasi nilai rapor dapat diketahui bahwa hasil belajar siswa di SMP Nusantara Makassar berada pada kategori baik dengan frekuensi 19 orang dan presentase $42,2 \%$. Adapun berdasarkan hasil olah data SPPS for Windows 21 diperoleh nilai mean sebesar 83,80 dengan standar deviasi sebesar 5,945 serta nilai varians sebesar 35,345.

\section{Pengaruh Tingkat Pendidikan Orang Tua Terhadap Hasil Belajar IPS Siswa di SMP Nusantara Makassar}

Berdasarkan hasil analisis regresi sederhana diperoleh persamaan garis regresi $\mathrm{Y}$ atas $\mathrm{X}_{1}$ adalah $\hat{\mathrm{Y}}=69,067+0,183 \mathrm{X}_{1}$.

Dalam perhitungan selanjutnya diperoleh harga $F_{\text {hitung }}$ sebesar 5,896> harga $\mathrm{F}_{\text {tabel }}$ Sebesar 4,067. Hal ini berarti $\mathrm{H}_{\mathrm{o}}$ ditolak dan $\mathrm{H}_{1}$ diterima. Dengan demikian, dapat disimpulkan bahwa: "Terdapat pengaruh tingkat pendidikan orang tua terhadap hasil belajar IPS siswa di SMP Nusantara Makassar".

Adapun nilai $r$ adalah sebesar 0,374 jika diinterpretasikan menurut Sugiyono (2010: 214) maka hubungan tingkat pendidikan orang tua $\left(\mathrm{X}_{1}\right)$ dengan hasil belajar IPS siswa (Y) di SMP Nusantara Makassar berada pada kategori rendah. Adapun nilai R Square sebesar 0,121, artinya $12,1 \%$ variabel terikat yaitu hasil belajar IPS dipengaruhi oleh variabel bebas yaitu tingkat pendidikan orang tua.

\section{Pengaruh Tingkat Pendapatan Orang Tua terhadap Hasil Belajar IPS Siswa di SMP Nusantara Makassar}

Berdasarkan hasil analisis regresi sederhana pada diperoleh persamaan garis regresi $\mathrm{Y}$ atas $\mathrm{X}_{2}$ adalah $\hat{\mathrm{Y}}=78,630+0,067 \mathrm{X}_{2}$.

Dalam perhitungan selanjutnya diperoleh harga $F_{\text {hitung }}$ sebesar $0,460<$ harga $\mathrm{F}_{\text {tabel }}$ sebesar 4,067. Hal ini berarti $\mathrm{H}_{1}$ ditolak dan $\mathrm{H}_{0}$ diterima. Dengan demikian, dapat disimpulkan bahwa: "Tidak terdapat pengaruh tingkat pendapatan orang tua terhadap hasil belajar IPS siswa di SMP Nusantara Makassar".

Adapun nilai $r$ adalah sebesar 0,103 jika diinterpretasikan menurut Sugiyono (2010: 214) maka hubungan tingkat pendapatan orang tua $\left(\mathrm{X}_{2}\right)$ dengan hasil belajar IPS siswa (Y) di SMP
Nusantara Makassar berada pada kategori sangat rendah. Adapun nilai R Square sebesar 0,011, artinya $0,11 \%$ variabel terikat yaitu hasil belajar IPS dipengaruhi oleh variabel bebas yaitu tingkat pendapatan orang tua.

4. Pengaruh Lingkungan Belajar terhadap Hasil Belajar IPS Siswa di SMP Nusantara Makassar

Berdasarkan hasil analisis regresi sederhana diperoleh persamaan garis regresi $\mathrm{Y}$ atas $\mathrm{X}_{3}$ adalah $\hat{Y}=46,562+0,438 \mathrm{X}_{3}$.

Dalam perhitungan selanjutnya diperoleh harga $\mathrm{F}_{\text {hitung }} 37,897>$ harga $\mathrm{F}_{\text {tabel }} 4,067$. Hal ini berarti $\mathrm{H}_{\mathrm{o}}$ ditolak dan $\mathrm{H}_{1}$ diterima. Dengan demikian, dapat disimpulkan bahwa: "Terdapat pengaruh lingkungan belajar terhadap hasil belajar IPS siswa di SMP Nusantara Makassar".

Adapun nilai $r$ adalah sebesar 0,684 jika diinterpretasikan menurut Sugiyono (2010: 214) maka hubungan lingkungan belajar $\left(X_{3}\right)$ dengan hasil belajar IPS siswa (Y) di SMP Nusantara Makassar berada pada kategori kuat. Adapun nilai R Square sebesar 0,468, artinya $46,8 \%$ variabel terikat yaitu hasil belajar IPS dipengaruhi oleh variabel bebas yaitu lingkungan belajar.

\section{Pengaruh Tingkat Pendidikan, Pendapatan Orang Tua dan Lingkungan Belajar terhadap Hasil Belajar IPS Siswa di SMP Nusantara Makassar}

Berdasarkan hasil analisis regresi berganda diperoleh persamaan garis regresi $\mathrm{Y}$ atas $\mathrm{X}_{1}, \mathrm{X}_{2}$, dan $\mathrm{X}_{3}$ adalah $\hat{\mathrm{Y}}=49,432+0,152 \mathrm{X}_{1}$ $+\left(-0,223 X_{2}\right)+0,464 X_{3}$.

Dalam perhitungan selanjutnya diperoleh harga $F_{\text {hitung }} 17,477>$ harga $F_{\text {tabel }}$ 2,833. Hal ini berarti $\mathrm{H}_{\mathrm{o}}$ ditolak dan $\mathrm{H}_{1}$ diterima. Dengan demikian, dapat disimpulkan bahwa: "Terdapat pengaruh secara simultan tingkat pendidikan, pendapatan orang tua dan lingkungan belajar terhadap hasil belajar IPS siswa di SMP Nusantara Makassar".

Adapun nilai $r$ adalah sebesar 0,749 jika diinterpretasikan menurut Sugiyono (2010: 214) maka hubungan tingkat pendidikan orang tua $\left(\mathrm{X}_{1}\right)$ pendapatan orang tua $\left(\mathrm{X}_{2}\right)$ dan lingkungan belajar $\left(\mathrm{X}_{3}\right)$ dengan hasil belajar IPS siswa (Y) di SMP Nusantara Makassar berada pada kategori kuat. Adapun nilai $\mathrm{R}$ Square sebesar 0,561 , artinya $56,1 \%$ variabel terikat yaitu hasil belajar IPS dipengaruhi oleh variabel bebas yaitu tingkat pendidikan, tingkat pendapatan orang tua, dan lingkungan belajar. 


\section{Pembahasan}

1. Pengaruh tingkat pendidikan orang tua secara parsial terhadap hasil belajar IPS siswa di SMP Nusantara Makassar

Tingkat pendidikan orang tua secara teoritis memiliki pengaruh terhadap hasil belajar anak. Dengan kata lain bahwa dengan tingkat pendidikan orang tua yang baik maka akan menciptakan hasil belajar yang baik pula. Tingkat pendidikan orang tua yang meliputi tingkat SMA, Diploma, S1, S2, serta S3. Hal ini perlu mendapatkan perhatian mengingat hal tersebut berpengaruh sangat besar dalam menunjang hasil belajar yang lebih baik.

Hal tersebut sejalan dengan pendapat Ahmadi (2003: 289) orang tua yang berpendidikan akan memberikan perhatian yang lebih pada anak terutama dalam bidang pendidikan dengan harapan di masa mendatang kualitas kehidupannya lebih baik dari sebelumnya.

Selain itu, menurut Slameto, (2013: 64) juga mengemukakan bahwa tingkat pendidikan atau kebiasan di dalam keluarga mempengaruhi sikap anak dalam belajar. Perlu kepada anak ditanamkan kebiasaan-kebiasaan yang baik, agar mendorong semangat anak untuk belajar.

Temuan penelitian ini sejalan dengan penelitian yang dilakukan oleh TetyNurCholifah, dkk. (2016) hasil penelitian menunjukkan ada pengaruh positif dan signifikan antara latar belakang tingkat pendidikan orangtua terhadap hasil belajar siswa dengan nilai R67,6\%.

2. Pengaruh tingkat pendapatan orang tua secara parsial terhadap hasil belajar IPS siswa di SMP Nusantara Makassar

Hasil penelitian ini ditemukan bahwa tingkat pendapatan orang tua tidak memiliki pengaruh terhadap hasil belajar IPS siswa di SMP Nusantara Makassar. Hasil penelitian ini dibuktikan dengan persentase tertinggi tingkat pendapatan orang tua yang berada pada kategori cukup sedangkan hasil belajar IPS siswa berada pada kategori baik. Maka dapat ditarik kesimpulan bahwa tingkat pendapatan orang tua tidak berpengaruh positif terhadap hasil belajar IPS siswa.

Anak yang berasal dari keluarga yang keadaan ekonomi cukup akan termovitasi untuk belajar dengan giat agar bisa memiliki hasil belajar yang baik, sehingga berpotensi untuk mendapatkan yang baik demi memenuhi kebutuhan hidup. Sebaliknya anak yang yang berasal dari keluarga yang keadaan ekonomi tinggi cenderung terlena dengan segala kebutuhan yang serba ada tanpa harus bekerja keras karena semua kebutuhan telah dipenuhi oleh orang tua. Hal tersebut membuat anak tidak berpikir untuk belajar dengan baik untuk mendapatkan hasil belajar yang baik sehingga mudah mendapatkan pekerjaan demi memenuhi kebutuhan hidup.

Hal tersebut sejalan dengan Slameto, (2013: 64) bahwa jika anak hidup dalam keluarga miskin, kebutuhan pokok anak kurang terpenuhi, akibatnya kesehatan terganggu, sehingga belajar anak juga terganggu. Akibat yang lain anak selalu dirundung kesedihan sehingga anak merasa minder dengan teman lain, hal ini pasti akan mengganggu belajar anak. Bahkan anak harus bekerja mencari nafkah sebagai pembantu orang tuanya walaupun sebenarnya anak belum saatnya untuk bekerja, hal yang begitu juga akan mengganggu belajar anak. Walaupun tidak dapat dipungkiri tentang adanya kemungkinan anak yang serba kekurangan dan selalu menderita akibat ekonomi keluarga yang lemah, justru keadaan begitu menjadi cambuk baginya untuk belajar giat dan akibatnya sukses besar.

Sebaliknya keluarga yang kaya raya, orang tua sering mempunyai kecenderungan untuk memanjakan anak. Anak hanya bersenang-senang dan berfoya-foya, akibatnya anak kurang dapat memusatkan perhatiannya kepada belajar. Hal tersebut juga dapat mengganggu belajar anak, sehingga prestasi belajarnya tidak memuaskan.

Temuan penelitian ini tidak sejalan dengan penelitian yang dilakukan Dwi Aprilia Matus (2016) yang berjudul "Pengaruh Tingkat Pendapatan dan Tingkat Pendidikan Orang Tua serta Disiplin Belajar terhadap Prestasi Belajar Siswa di SMA Negeri di Bangkalan". Hasil penelitian hasil penelitian menunjukkan bahwa terdapat pengaruh tingkat pendapatan orang tua terhadap prestasi belajar dengan nilai signifikansi $0,036<5 \%$.

Sehingga dapat dikatakan pendapatan orang tua tidak bisa menjamin meningkatkan hasil belajar IPS siswa, karena tidak sesuai dengan penelitian sebelumnya yang menunjukkan terdapat pengaruh tingkat pendapatan orang tua terhadap prestasi belajar. Tidak adanya pengaruh positif dalam penelitian inni dapat disebabkan oleh berbagai faktor, baik orang tua maupun siswa. 
Adapun faktor hasil belajar IPS yang dicapai siswa dipengaruhi oleh faktor yang berada dalam diri individu yang sedang belajar terutama kemampuan yang dimilikinya. Hal ini sesuai dengan yang disampaikan Suryabrata (2014: 236) dan Dalyono (2015: 56) menyatakan hasil belajar yang diperoleh seseorang dipengaruhi oleh faktor internal yang berasal dari dalam diri siswa yaitu intelegensi dan bakat. Intelegensi dan bakat ini besar sekali pengaruhnya terhadap kemampuan belajar. Seseorang yang memiliki intelegensi yang baik umumnya mudah belajar dan hasilnya pun cenderung baik. Bakat, juga besar pengaruhnya dalam menentukan keberhasilan belajar. Misalnya belajar main piano, apabila dia memiliki bakat musik, akan lebih mudah dan cepat pandai dibandingkan dengan orang yang tidak memiliki bakat itu.

Selanjutnya, bila seseorang mempunyai bakat intelegensi tinggi dan bakatnya ada dalam bidang yang dipelajari, maka proses belajarnya akan lancar dan sukses bila dibandingkan dengan orang yang memiliki bakat saja tetapi intelegensinya rendah.

\section{Pengaruh lingkungan belajar secara parsial terhadap hasil belajar IPS siswa di SMP Nusantara Makassar}

Hasil penelitian ini ditemukan bahwa lingkungan belajar siswa memiliki pengaruh yang positif dan signifikan terhadap hasil belajar IPS siswa di SMP Nusantara Makassar. Hal tersebut diperkuat dari hasil rekap angket bahwa dalam lingkungan keluarga, orang tua tidak menyalahkan televisi pada saat belajar, dalam lingkungan sekolah, teman sekelas saling membantu dalam menyelesaikan tugas begitupun dengan guru IPS sering membantu dalam memahami materi yang dianggap sulit, serta siswa menggunakan buku paket yang dianjurkan oleh guru agar lebih mudah dalam proses pembelajaran. Selain itu, dapat juga dilihat pada lampiran tentang gambaran kondisi lingkungan belajar siswa yang tersedia $A C$, lampu penerangan yang memadai, serta lantai yang bersih.

Hasil penelitian tersebut didukung pendapat Dalyono (2015: 55) mengemukakan faktor yang mempengaruhi belajar yaitu faktor eksternal yang meliputi:

\section{a. Keluarga}

Keluarga adalah ayah, ibu, dan anakanak serta family yang menjadi penghuni rumah. Faktor orang tua sangat besar pengaruhnya terhadap keberhasilan anak dalam belajar.
Tinggi rendahnya pendidikan orang tua, besar kecilnya penghasilan, cukup atau kurang perhatian dan bimbingan orang tua, rukun atau tidaknya kedua orang tua, akrab atau tidaknya orang tua dengan anak-anak, tenang atau tidaknya situasi dalam rumah, semuanya itu turut mempengaruhi pencapaian hasil belajar anak. Di samping itu, faktor keadaan rumah juga turut mempengaruhi pencapaian hasil belajar anak. Besar kecilnya rumah tempat tinggal, ada atau tidaknya peralatan/media belajar seperti papan tulis, gambar, peta, ada atau tidaknya kamar atau meja belajar, dan sebagainya, semuanya itu juga turut menentukan keberhasilan belajar seseorang.

b. Sekolah

Keadaan sekolah tempat belajar turut mempengaruhi tingkat keberhasilan belajar. Kualitas guru, metode mengajarnya, kesesuaian kurikulum dengan kemampuan anak, keadaan fasilitas/perlengkapan di sekolah, keadaan ruangan, jumlah murid per kelas, pelaksanaan tata tertib sekolah, dan sebagainya, semua itu turut mempengaruhi keberhasilan belajar anak. Bila suatu sekolah kurang memperhatikan tata tertib (disiplin), maka murid-muridnya kurang mematuhi perintah para guru dan akibatnya mereka tidak mau belajar sungguh-sungguh di sekolah maupun di rumah. Hal ini mengakibatkan prestasi belajar anak murid menjadi rendah. Demikian pula jika jumlah murid per kelas terlalu banyak (50-60 orang), dapat mengakibatkan kelas kurang tenang, hubungan guru dengan murid kurang akrab, kontrol guru menjadi lemah, murid menjadi kurang acuh terhadap gurunya, sehingga motivasi belajar menjadi lemah.

c. Masyarakat

Keadaan masyarakat juga menentukan prestasi belajar. Bila di sekitar tempat tinggal keadaan masyarakat terdiri dari orang-orang yang berpendidikan, terutama anak-anaknya rata-rata bersekolah tinggi dan moralnya baik, hal ini akan mendorong anak lebih giat belajar. Tetapi sebaliknya, apabila tinggal di lingkungan banyak anak-anak yang nakal, tidak bersekolah dan pengangguran, hal ini akan mengurangi semangat belajar atau dapat dikatakan tidak menunjang sehingga motivasi belajar berkurang.

\section{d. Lingkungan sekitar}

Keadaan lingkungan tempat tinggal, juga sangat penting dalam mempengaruhi prestasi belajar. Keadaan lingkungan, bangunan rumah, suasana sekitar, keadaan lalu lintas, iklim, dan sebagainya. Misalnya bila bangunan 
rumah penduduk sangat rapat, akan mengganggu belajar. Keadaan lalu lintas yang membisingkan, suara hiruk pikuk orang disekitar, suara pabrik, polusi udara, iklim yang terlalu panas. Semuanya ini akan mempengaruhi kegairahan belajar. Sebaliknya, tempat yang sepi dengan iklim yang sejuk, ini akan menunjang proses belajar.

Selain itu, juga dikemukakan oleh Martensi dalam Ihsan (2013: 37) salah satu faktor yang mempengaruhi anak dalam belajar yaitu lingkungan fisik dan non fisik yang kurang/tidak menguntunkan. Misalnya, lingkungan tetangga yang senang berjudi, penyabung ayam, pencopet dan sebagainya akan mempengaruhi anak kearah yang perbuatan yang tidak baik pula. Demikian pula mass media ( $\mathrm{TV}$, radio, film, surat kabar, majalah dan sebagainya), bila tidak dikelola dengan baik dapat merugikan anak dalam belajar. Malah kadang-kadang akan menjadi penyebab kegagalan bagi anak.

Temuan penelitian ini sejalan dengan hasil penelitian Sumiati (2012 hasil penelitian menunjukkan ada pengaruh positif lingkungan keluarga, lingkungan sekolah, lingkungan masyarakat dan motivasi belajar siswa hasil belajar siswa.

\section{Pengaruh tingkat pendidikan, pendapatan orang tua dan lingkungan belajar secara simultan terhadap hasil belajar IPS siswa di SMP Nusantara Makassar}

Hasil penelitian ini ditemukan bahwa tingkat pendidikan, pendapatan orang tua dan lingkungan belajar secara simultan berpengaruh terhadap hasil belajar IPS siswa di SMP Nusantara Makassar. Tingkat pendidikan orang tua, pendapatan orang tua dan lingkungan belajar siswa di SMP Nusantara Makassar berada pada kategori baik berdampak pada hasil belajar siswa yang baik.

Dengan adanya tingkat pendidikan orang tua yang baik serta didukung oleh tingkat pendapatan orang tua yang cukup maka orang tua dapat secara bijaksana dalam memenuhi kebutuhan anaknya dalam menciptakan lingkungan belajar yang kondusif. Lingkungan belajar yang dimaksud dalam penelitian ini meliputi lingkungan keluarga, sekolah dan masyarakat.

Hal tersebut sesuai dengan pendapat Slameto, 2013: 54 faktor-faktor yang mempengaruhi belajar yaitu:

a. Faktor keluarga meliputi: cara orang tua mendidik, relasi antar anggota keluarga, suasana rumah, keadaan ekonomi keluarga, pengertian orang tua, serta latar belakang kebudayaan/tingkat pendidikan orang tua.

b. Faktor sekolah meliputi: metode mengajar, kurikulum, relasi guru dengan siswa, relasi siswa dengan siswa, disiplin sekolah, alat pelajaran, waktu sekolah, standar pelajaran di atas ukuran, keadaan gedung, metode belajar, serta tugas rumah.

c. Faktor masyarakat meliputi: kegiatan siswa dalam masyarakat, mass media, teman bergaul, serta bentuk kehidupan masyarakat.

\section{SIMPULAN DAN SARAN}

Berdasarkan hasil yang didapat dalam penelitian ini serta analisis data yang telah dilakukan maka dapat disimpulkan bahwa: (1) Terdapat pengaruh positif tingkat pendidikan orang tua terhadap hasil belajar IPS siswa di SMP Nusantara Makassar. (2) Tidak terdapat pengaruh tingkat pendapatan orang tua terhadap hasil belajar IPS siswa di SMP Nusantara Makassar. (3) Terdapat pengaruh positif lingkungan belajar terhadap hasil belajar IPS siswa di SMP Nusantara Makassar. (4) Terdapat pengaruh positif tingkat pendidikan, tingkat pendapatan orang tua, dan lingkungan belajar secara simultan terhadap hasil belajar IPS siswa di SMP Nusantara Makassar.

Berdasarkan kesimpulan, maka diajukan saran-saran yaitu: (1) Melihat pengaruh positif tingkat pendidikan orang tua terhadap hasil belajar maka sebagai orang tua sebaiknya dibekali dengan pengetahuan dan keterampilan pendidikan yang memadai agar dapat mendidik anaknya. Karena, pendidikan yang diterima dalam keluargalah yang akan digunakan oleh anak sebagai dasar untuk mengikuti pendidikan selanjutnya di sekolah; (2) Melihat tidak terdapat pengaruh pendapatan orang tua terhadap hasil belajar maka pendapatan orang tua harus didukung oleh pendidikan yang memadai, supaya orang tua dapat mengerti kebutuhan-kebutuhan yang diperlukan anak dalam mendukung kelancaran proses belajar sehingga tercapai hasil belajar yang maksimal. Selain itu, intelegensi dan bakat anak harus dikembangkan sesuai dengan kemampuan anak; (3) Melihat pengaruh positif lingkungan belajar terhadap hasil belajar maka orang tua dalam penelitian ini selaku lingkungan keluarga, guru dalam penelitian ini selaku lingkungan sekolah, serta anggota masyarakat dalam hal ini selaku 
lingkungan masyarakat harus bekerja sama dalam menciptakan lingkungan belajar yang baik untuk anak sehingga tercipta hasil belajar yang baik pula; (4) Melihat pengaruh positif tingkat pendidikan, pendapatan orang tua, dan lingkungan belajar secara bersama-sama terhadap hasil belajar maka perlu dipenuhi dengan baik ketiga variabel tingkat pendidikan, tingkat pendapatan dan lingkungan belajar untuk menciptakan hasil belajar IPS siswa yang baik di SMP Nusantara Makassar.

\section{DAFTAR RUJUKAN}

Ahmadi, A. 2003.Ilmu Sosial Dasar. Jakarta: Rineka Cipta.

Cholifah, T. N., INyoman S.D., Sugeng U. 2016. Pengaruh Latar Belakang Tingkat Pendidikan Orang Tua dan Gaya Belajar terhadap Hasil Belajar Siswa pada Kelas IV SDN Kecamatan Sawanwetan Kota Blitar. Jurnal Pendidikan. Volume: 1 Nomor: 3 Bulan Maret Tahun 2016 Halaman: 486-491.

Dalyono. 2015. Psikologi Pendidikan. Jakarta: Rineka Cipta.

Djamarah, S. B. 2015. Psikologi Belajar. Jakarta: Rineka Cipta.

Hamalik, O. 2015. Proses Belajar Mengajar. Jakarta: PT Bumi Aksara.

Hamran. 2016. Pengaruh Kondisi Sosial dan Ekonomi Orang Tua Terhadap Motivasi Melanjutkan Pendidikan Ke Perguruan Tinggi pada Siswa SMK 1 Palangga Kabupaten Gowa. Tesis. Makassar : Program Studi Pendidikan IPS. Program Pascasarjana Universitas Negeri Makassar.

Ihsan, F. 2013. Dasar - Dasar Kependidikan. Jakarta: Rineka Cipta.

Matus, D. A., 2016. Pengaruh Tingkat Pendapatan dan Tingkat Pendidikan Orang Tua serta Disiplin Belajar terhadap Prestasi Belajar Siswa SMA Negeri di Bangkalan. Jurnal Ekonomi dan Pendidikan Kewirausahaan. Volume: 4 Nomor 2 Tahun 2016.
Munarfah, A., \& Muhammad, H. 2009. Metode Peneltian. Jakarta: CV. Praktika Aksara Semesta.

Nasution. 2014. Sosiologi Pendidikan. Jakarta: Bumi Aksara.

Nokwanti. 2013. Pengaruh Tingkat Disiplin dan Lingkungan Belajar di Sekolah terhadap Prestasi Belajar Siswa. Artikel Jurnal. Ekonomi IKIP Veteran Semarang.

Rizkiana, A. 2014. Pengaruh Status Sosial Ekonomi Orang Tua, Motivasi Belajar, Disiplin Belajar, terhadap Prestasi Belajar pada Siswa SMK Barunawati Surabaya. Jurnal Ekonomi Pendidikan dan Kewiarausahaan. Volume 2 Nomor 2 Tahun 2014.

Rohani, A. 2010. Sebuah Pengantar Menuju Guru Profesional. Jakarta: Rineka Cipta.

Sapruddin., dkk. 2017. Kondisi Sosial Ekonomi Orang Tua dan Motivasi Belajar terhadap Prestasi Belajar Ilmu Pengetahuan Sosial. Tesis. Program Studi Pendidikan Dasar Pascasarjana Universitas Negeri Malang.

Slameto. 2013. Belajar dan Faktor-Faktor yang Mempengaruhi. Jakarta: Rineka Cipta.

Sudjana, N. 2014. Dasar-Dasar Proses Belajar Mengajar. Bandung: Sinar Baru Algesindo.

Sugiyono. 2010. Metode Penelian Pendidikan (Pendekatan Kuantitatif, Kualitatif, dan $R \& D)$. Bandung: Alfabeta.

Sukardi. 2012.MetodePenelitian Pendidikan.Jakarta:BumiAksara.

Sumiati. 2012. Pengaruh Lingkungan Belajar Siswa terhadap Motivasi Belajar dan Implikasinya terhadap Hasil Belajar Siswa pada Mata Pelajaran Ekonomi Syariah di SMP Kota Tasikmalaya (Survei pada Siswa SMP Se-Kota Tasikmalaya). Jurnal Sains dan Terapan. Volume: 7 Nomor 1 Tahun 2012. 
Phinisi Integration Review. Vol 1(2) Agustus 2018

Suprapto. 2013. Metodologi Penelitian Ilmu Pendidikan dan Ilmu-Ilmu Pengetahuan Sosial.Yogyakarta: CAPS.

Suryabrata, S. 2014. Psikologi Pendidikan. Jakarta: Rajawali Pers.

Susanto, A. 2014. Pengembangan Pembelajaran IPS di Sekolah Dasar. Jakarta: Kencana.

Syah, M. 2012. Psikologi Belajar. Jakarta: Rajawali Pers.

2016. Psikologi Pendidikan Dengan Pendekatan Baru.
Bandung: $\quad$ PT Remaja

Rosdakarya.

UU RI No. 20 Tahun 2013 tentang SIKDIKNAS (Sistem Pendidikan Nasional). Jakarta: Sinar Grafika.

Wahab, R. 2015. Psikologi Belajar. Jakarta: Rajawali Pers.

Website Resmi Pemerintah Provinsi Sulawesi Selatan. 2016. UMP Sulsel 2017 Rp.2.500.000. (Online), (http://sulselprov.go.id. diakses 7 Agustus 2017). 